Research

\title{
Female smokers beyond the perimenopausal period are at increased risk of chronic obstructive pulmonary disease: a systematic review and meta-analysis \\ Wen Qi Gan ${ }^{1,2}$, SF Paul Man¹,2, Dirkje S Postma ${ }^{3}$, Patricia Camp ${ }^{1}$ and \\ Don D Sin*1,2
}

Address: ${ }^{1}$ James Hogg iCAPTURE Center for Cardiovascular and Respiratory Research, University of British Columbia, Vancouver, B.C., Canada, ${ }^{2}$ Department of Medicine (Pulmonary Division), University of British Columbia, Vancouver, B.C., Canada and ${ }^{3}$ Department of Pulmonology, University Hospital, University of Groningen, Groningen, The Netherlands

Email: Wen Qi Gan - wgan@mrl.ubc.ca; SF Paul Man - pman@providencehealth.bc.ca; Dirkje S Postma - d.s.postma@int.umcg.nl; Patricia Camp - pcamp@unix.infoserve.net; Don D Sin* - dsin@mrl.ubc.ca

* Corresponding author

Published: 29 March 2006

Respiratory Research2006, 7:52 doi:10.1 186//465-9921-7-52
Received: 20 January 2006

Accepted: 29 March 2006

This article is available from: http://respiratory-research.com/content/7///52

(c) 2006Gan et al; licensee BioMed Central Ltd.

This is an Open Access article distributed under the terms of the Creative Commons Attribution License (http://creativecommons.org/licenses/by/2.0), which permits unrestricted use, distribution, and reproduction in any medium, provided the original work is properly cited.

\begin{abstract}
Background: Recent reports indicate that over the next decade rates of chronic obstructive pulmonary disease (COPD) in women will exceed those in men in the western world, though in most jurisdictions, women continue to smoke less compared with men. Whether female adult smokers are biologically more susceptible to COPD is unknown. This study reviewed the available evidence to determine whether female adult smokers have a faster decline in forced expiratory volume in one second $\left(\mathrm{FEV}_{1}\right)$ compared with male adult smokers and whether age modifies the relationship between cigarette smoke and lung function decline.

Methods: A systematic review and a meta-analysis was performed of population-based cohort studies that had a follow-up period of at least 3 years, measured FEV , on at least two different time points, and presented FEV, data stratified by gender and smoking status in adults.

Results: Of the 646 potentially relevant articles, II studies met these criteria and were included in the analyses ( $N=55709$ participants). There was heterogeneity in gender-related results across the studies. However, on average current smokers had a faster annual decline rate in $F E V_{1} \%$ predicted compared with never and former smokers. Female current smokers had with increasing age a significantly faster annual decline in $\mathrm{FEV}_{1} \%$ predicted than male current smokers (linear regression analysis, $R^{2}=0.56 ; p=0.008$ ). Age did not materially affect the rate of decline in $F E V_{1} \%$ predicted in male and female former and never smokers $(p=0.775$ and $p=0.326$, respectively).

Conclusion: As female smokers age, they appear to experience an accelerated decline in $\mathrm{FEV}_{1} \%$ predicted compared with male smokers. Future research powered specifically on gender-related changes in lung function is needed to confirm these early findings.
\end{abstract}

\section{Background}

Chronic obstructive pulmonary disease (COPD) is a major cause of death in North America and Europe and the only major disease for which the morbidity and mor- 
Table I: Characteristics of studies included in meta-analyses*

\begin{tabular}{|c|c|c|c|c|c|}
\hline Source & Project name & Sample size & Women (\%) & $\begin{array}{l}\text { Average age at } \\
\text { baseline (year) }\end{array}$ & $\begin{array}{l}\text { Duration of follow } \\
\text { up (year) }\end{array}$ \\
\hline Viegi et al,22 200I & $\begin{array}{l}\text { Po River Delta Epidemiologic Study, } \\
\text { North Italy }\end{array}$ & 1774 & 51 & 32 & 8 \\
\hline Chinn et al, 122005 & $\begin{array}{l}\text { European Community Respiratory } \\
\text { Health Survey II, } 27 \text { centers, } 26 \text { were in } \\
\text { western Europe and one was in the } \\
\text { USA }\end{array}$ & 6654 & 51 & 34 & 9 \\
\hline Rijcken et al, ${ }^{3}$ । 995 & $\begin{array}{l}\text { Vlagtwedde-Vlaardingen study in the } \\
\text { Netherlands }\end{array}$ & 1619 & 43 & 39 & 25 \\
\hline $\begin{array}{l}\text { Jedrychowski et al, }{ }^{14} \\
\text { 1986 }\end{array}$ & Cracow Study in Cracow, Poland & 1364 & 64 & 40 & 13 \\
\hline James et al, ${ }^{15} 2005$ & $\begin{array}{l}\text { Busselton Health Study in Busselton, } \\
\text { Western Australia }\end{array}$ & 9317 & 51 & 42 & 29 \\
\hline Tashkin et al, ${ }^{16} \mid 984$ & $\begin{array}{l}\text { UCLA Population Studies in Los } \\
\text { Angeles County, USA }\end{array}$ & 2401 & 54 & 46 & 5 \\
\hline Sherrill et al, ${ }^{17} 1996$ & $\begin{array}{l}\text { Tucson Epidemiology Study of } \\
\text { Obstructive Lung Disease in Tucson, } \\
\text { Arizona, USA }\end{array}$ & 477 & 41 & 48 & 8 \\
\hline Connett et al, ${ }^{23} 2003 \dagger$ & $\begin{array}{l}\text { Lung Health Study, } 10 \text { centres, nine in } \\
\text { the USA, one in Canada }\end{array}$ & 5346 & 37 & 48 & 5 \\
\hline Xu et al, ${ }^{18} 1992$ & Six Cities Study in the USA & 12080 & 55 & 49 & 6 \\
\hline Vestbo et al, ${ }^{19} 1996$ & $\begin{array}{l}\text { Copenhagen City Heart Study, } \\
\text { Denmark }\end{array}$ & 9435 & 57 & 53 & 5 \\
\hline Griffith et al, ${ }^{20} 200 \mathrm{I}$ & Cardiovascular Health Study in the USA & 5242 & 57 & 73 & 7 \\
\hline
\end{tabular}

Symbols: *: Order in table: average age at baseline; $\dagger:$ The participants were smokers with mild-to-moderate COPD.

tality are still increasing in these continents $[1,2]$. Although COPD is currently the 4th-leading cause of mortality and the 12th-leading cause of disability, by the year 2020 it will be the 3rd-leading cause of death and the 5thleading cause of disability worldwide [3,4]. Strikingly, this projected increase in COPD-related morbidity and mortality will be driven largely by the female population, a trend that started 20 years ago [5]. Some have ascribed this trend to increased smoking rates in women over the past two decades [6]. However, there are likely to be other factors involved. While female smoking rates have indeed increased relative to male rates since the 1970 's, female smoking rates continue to be lower than those for men $[5,7]$. For example, in the US in 2003, 19\% of adult women smoked versus $24 \%$ of adult men [8]. Moreover, even when women smoke, they consume on average fewer cigarettes per day and have lower serum cotinine levels compared with men, indicating that cigarette smoke exposure per se cannot account for the rising COPD burden in women [9]. These data raise the possibility that female smokers may be biologically more susceptible to COPD compared to male smokers. We conducted a systematic review and a meta-analysis to determine whether female smokers do or do not have increased susceptibility to COPD compared with male smokers. Additionally, since age is a major determinant of changes in lung function [10], we sought to determine whether age modified the relationship between smoking and lung function decline in both men and women.

\section{Methods}

\section{Search for relevant studies}

Using PUBMED (1966-January 2006) and EMBASE (1980-January 2006) electronic databases, we conducted a comprehensive literature search to identify studies related to the decline of lung function published before January 2006. We used lung function sensitive terms (forced expiratory volume, vital capacity) combined with design sensitive terms (cohort studies, longitudinal studies, follow-up studies, prospective studies), and smoking sensitive terms (smoke, cigarette, smoking) in our searches. The electronic searches were supplemented by scanning of the reference lists from retrieved articles to identify additional studies that may have been missed during the electronic search. We also contacted the primary authors of retrieved studies for additional data and/ or clarification of data, where necessary.

\section{Study selection and data abstraction}

The primary objective of this study was to compare the annual decline of lung function, measured as percent predicted forced expiratory volume in one second $\left(\mathrm{FEV}_{1} \%\right.$ pred), which is an important phenotype of COPD [11], between men and women stratified according to smoking status. To mitigate methodological biases, we limited our search to studies that: (1) were population-based; (2) employed a longitudinal cohort design; (3) had a followup of at least 3 years; (4) measured $\mathrm{FEV}_{1}$ on at least two different time points; and (5) presented $\mathrm{FEV}_{1}$ data strati- 
Table 2: Annual decline rate in $\mathrm{FEV}_{1} \% \mathrm{pred} / \mathrm{yr}$ in men and women according to smoking status

\begin{tabular}{|c|c|c|c|c|c|c|c|c|c|c|}
\hline \multirow[t]{2}{*}{ Source } & \multirow{2}{*}{$\begin{array}{l}\text { Average age at } \\
\text { baseline (year) }\end{array}$} & \multicolumn{3}{|c|}{ Never smokers } & \multicolumn{3}{|c|}{ Former smokers } & \multicolumn{3}{|c|}{ Current smokers } \\
\hline & & Women & Men & Difference* & Women & Men & Difference* & Women & Men & Difference* \\
\hline Viegi et al,22 200l & 32 & NA & NA & NA & -0.12 & -0.21 & 0.09 & 0.12 & 0.13 & -0.01 \\
\hline$C$ hinn et al, ${ }^{12} 2005$ & 34 & 0.78 & 0.76 & 0.02 & 0.91 & 0.76 & 0.15 & 0.88 & 0.84 & 0.04 \\
\hline Rijcken et al, ${ }^{3}$ I 995 & 39 & 0.83 & 0.96 & -0.13 & 0.89 & 0.87 & 0.02 & 0.97 & 1.11 & -0.14 \\
\hline $\begin{array}{c}\text { Jedrychow ski et } \\
\text { al, }{ }^{14} \text { | } 9866\end{array}$ & 40 & 1.35 & 1.13 & 0.22 & NA & NA & NA & 1.41 & 1.46 & -0.05 \\
\hline James et al, ${ }^{15} 2005$ & 42 & 0.87 & 0.91 & -0.04 & 0.99 & 1.01 & -0.02 & 1.05 & 1.22 & -0.17 \\
\hline $\begin{array}{c}\text { Tashkin et al, } 16 \\
1984\end{array}$ & 46 & 1.51 & 1.70 & -0.19 & 1.36 & 1.65 & -0.29 & 1.97 & 2.15 & -0.18 \\
\hline Sherrill et al, ${ }^{17} 1996$ & 48 & 0.50 & 0.44 & 0.06 & 0.49 & 0.85 & -0.36 & 0.66 & 0.49 & 0.17 \\
\hline $\begin{array}{c}\text { Connett et al, }{ }^{23} \\
2003\end{array}$ & 48 & NA & NA & NA & 0.37 & 0.07 & 0.30 & 1.20 & 1.05 & 0.15 \\
\hline Xu et al, ${ }^{18} \mid 992$ & 49 & 1.08 & 0.98 & 0.10 & 1.11 & 0.89 & 0.22 & 1.42 & 1.37 & 0.05 \\
\hline
\end{tabular}

Each cell represents annual change in $\mathrm{FEV} \%$ pred/yr, unless otherwise indicated.

Symbols: *:A positive number denotes a larger decline in $\mathrm{FEV}, \%$ pred in women; a negative number denotes a large decline in $\mathrm{FEV}, \%$ pred in men; $\dagger$ : Never smokers and former smokers were combined as non-smokers in the article since they did not differ in $\mathrm{FEV}, \%$ pred decline.

fied by gender and smoking status. We excluded cross-sectional studies, or studies that evaluated occupational exposures on lung function. We also excluded studies whose primary focus was on secondhand smoke exposures. From each retrieved article, two independent investigators abstracted the following information: project name, sample size, average age at baseline, proportionality of women, duration of follow up, and annual decline rate of $\mathrm{FEV}_{1} \%$ pred stratified by gender and smoking status (Table 1, Table 2). Any questions or discrepancies regarding these data were resolved through iteration and consensus.

\section{Statistical analysis}

We used the annual change in the rate of $\mathrm{FEV}_{1} \%$ pred reported in the studies to conduct the primary analyses. Annual changes in $\mathrm{FEV}_{1} \%$ pred were calculated by subtracting the final $\mathrm{FEV}_{1} \%$ pred from the baseline value and dividing the difference by the number of years of followup. For studies that only provided absolute $\mathrm{FEV}_{1}$ values [12-20], we calculated $\mathrm{FEV}_{1} \%$ pred by applying a published prediction equation to the absolute values [21]. The reported baseline mean age and height were used in these calculations. For studies that did not report data on the subjects' height [12,14,17-19], we imputed $174 \mathrm{~cm}$ for men and $161 \mathrm{~cm}$ for women because the populations of these studies had similar race and age profiles as those reported in James's study (Table 2) [15]. We compared the annual changes in $\mathrm{FEV}_{1} \%$ pred between women and men across smoking status by using male values as the referent. A positive value denoted a larger decline in women, while a negative value denoted a larger decline in men. We hypothesized that age might be an important modifier for the relationship between smoking and gender-related decline in lung function since the incidence of obstructive airways disease in women increases sharply in the postmenopausal period [5]. We used both unweighted and weighted linear regression techniques to assess genderrelated differences in the annual decline of $\mathrm{FEV}_{1} \%$ pred. In the weighted analysis, we used the sample size of men and women in each smoking category as the weights. All tests were two-tailed in nature and were performed using statistical software SAS (version 9.1, SAS Institute, Carey, N.C).

\section{Results}

A summary of the search strategy is shown in Figure 1. The original search yielded 466 and 180 citations in PUBMED and EMBASE, respectively. The abstracts of these articles were selected and reviewed. Of these, 67 articles were retrieved for a detailed review. After excluding studies that used identical cohorts $(\mathrm{n}=41)$ and studies that had insufficient data $(\mathrm{n}=15)$, we were left with 11 original studies that met the inclusion criteria. The baseline characteristics of these studies are summarized in Table 1. Collectively, there were 55709 participants in these studies, 52\% were women, and the baseline average age of the cohorts varied from 32 to 73 years. The duration of follow-up ranged from 5 to 29 years.

Table 2 summarizes the annual decline in $\mathrm{FEV}_{1} \%$ pred in both men and women according to smoking status. In general, older cohorts experienced a faster decline in $\mathrm{FEV}_{1} \%$ pred/yr compared with younger cohorts and current smokers had a faster decline in $\mathrm{FEV}_{1} \%$ pred/yr compared with never smokers. Former smokers had similar decline rates in $\mathrm{FEV}_{1} \%$ pred/yr as never smokers. There were four studies that provided data on lung function changes stratified by the mean daily consumption of ciga- 


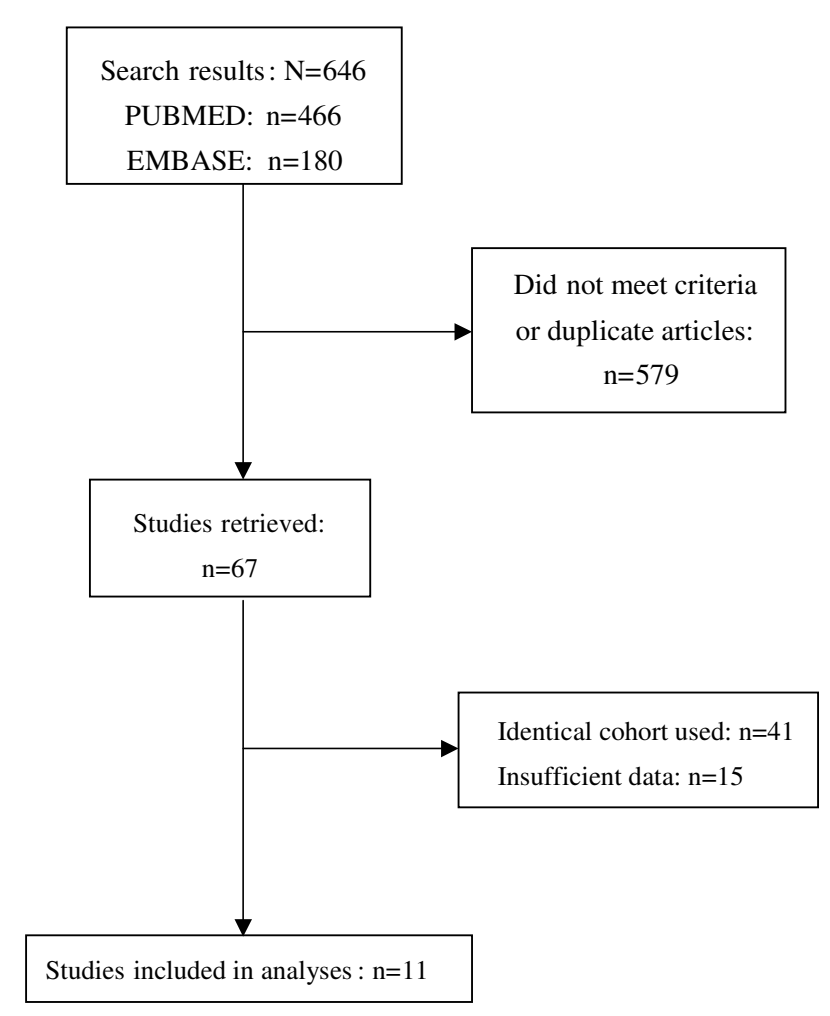

Figure I

Flow diagram of study selection.

rettes $[15,18,19,22]$. There was a dose-dependent acceleration in the decline of $\mathrm{FEV}_{1} \%$ pred/yr (Table 3 ).

In current smokers, with increasing age, women had a significantly faster decline in $\mathrm{FEV}_{1} \%$ pred/yr compared with men $\left(\mathrm{R}^{2}=0.56 ; \mathrm{p}=0.008\right)$, while in former and never smokers, age did not significantly modify the rate of decline in $\mathrm{FEV}_{1} \%$ pred/yr between men and women ( $\mathrm{p}=$ 0.775 and $\mathrm{p}=0.326$, respectively) (Figure 2 ). There were no material differences in the results between the weighted and unweighted analyses. The three average age- difference in $\mathrm{FEV}_{1} \%$ pred/yr regression lines diverged at $\sim 45$ to 50 years of age. As a sensitivity assessment, we repeated the analysis after excluding the study by Griffith and colleagues [20], which appeared to an outlier in Figure 3 . In the sensitivity analysis, female compared with male smokers still had a faster decline in $\mathrm{FEV}_{1} \%$ pred/yr $\left(\mathrm{R}^{2}=0.40 ; \mathrm{p}=0.050\right)$, while in former smokers and never smokers, there were no gender differences (in former smokers, $\mathrm{R}^{2}=0.14 ; \mathrm{p}=0.323$; in never smokers, $\mathrm{R}^{2}=0.28$ and $\mathrm{p}=0.179$ ).

\section{Discussion}

The present systematic review indicates that female compared with male smokers experienced a faster decline in lung function beyond age 45 to 50 years. This trend was evident even in female smokers who smoked only a modest amount of cigarettes (<15 g/day). In non- or ex-smokers, there were no significant gender-related changes in $\mathrm{FEV}_{1} \%$ pred over time. However, there was considerable heterogeneity in the results across the studies (see table 2 and figure 3 ) and as such these data should be interpreted cautiously. Additional prospective longitudinal studies powered specifically on gender-related changes in lung function in the post-menopausal age group are needed to confirm these observations.

The findings from the present study are consistent with other studies, which were not included in this review [2129]. Prescott and colleagues reported similar findings from two independent population samples: Copenhagen City Heart Study (CCHS) and Glostrup Population Studies (GPS) [24]. In both samples, when adjusted for packyears of smoking, female smokers had a faster decline in lung function compared with male smokers. In the CCHS, the estimated excess loss of $\mathrm{FEV}_{1}$ was $7.4 \mathrm{ml}$ per pack-year in female current smokers and $6.3 \mathrm{ml}$ per pack-year in male current smokers. In the GPS, the estimated excess loss of $\mathrm{FEV}_{1}$ was $10.5 \mathrm{ml}$ per pack-year in the female current smokers and $8.4 \mathrm{ml}$ per pack-year in the male current smokers. Importantly, in both samples, even after adjust-

Table 3: Annual decline rate in $\mathrm{FEV}_{1} \%$ pred/yr for female and male current smokers stratified by the daily amount of cigarette consumption

\begin{tabular}{|c|c|c|c|c|c|c|c|c|c|c|}
\hline \multirow[t]{2}{*}{ Source } & \multirow{2}{*}{$\begin{array}{l}\text { Average age at } \\
\text { baseline (year) }\end{array}$} & \multicolumn{3}{|c|}{ Never smokers } & \multicolumn{3}{|c|}{$<15$ g/day } & \multicolumn{3}{|c|}{15 g/day } \\
\hline & & Women & Men & Difference* & Women & Men & Difference* & Women & Men & Difference* \\
\hline Viegi et al,22 200I & 32 & NA & NA & NA & 0.08 & 0.12 & -0.04 & 0.22 & 0.15 & 0.07 \\
\hline James et al, ${ }^{15} 2005$ & 42 & 0.87 & 0.91 & -0.04 & 0.97 & 1.12 & -0.15 & 1.13 & 1.26 & -0.13 \\
\hline Xu et al, ${ }^{18} 1992$ & 49 & 1.08 & 0.98 & 0.10 & 1.16 & 0.97 & 0.19 & 1.51 & 1.44 & 0.07 \\
\hline Vestbo et al,' ' I996 & 53 & 1.00 & 0.83 & 0.17 & 1.23 & 0.98 & 0.25 & 1.32 & 1.22 & 0.10 \\
\hline Total & -- & 0.99 & 0.91 & 0.08 & 1.10 & 0.95 & 0.15 & 1.35 & 1.23 & 0.12 \\
\hline
\end{tabular}

Each cell represents annual change in $\mathrm{FEV}, \%$ pred, unless otherwise indicated.

Symbols: *: A positive number denotes a larger decline in $\mathrm{FEV}_{1} \%$ pred in women; a negative number denotes a larger decline in $\mathrm{FEV}, \%$ pred in men. 


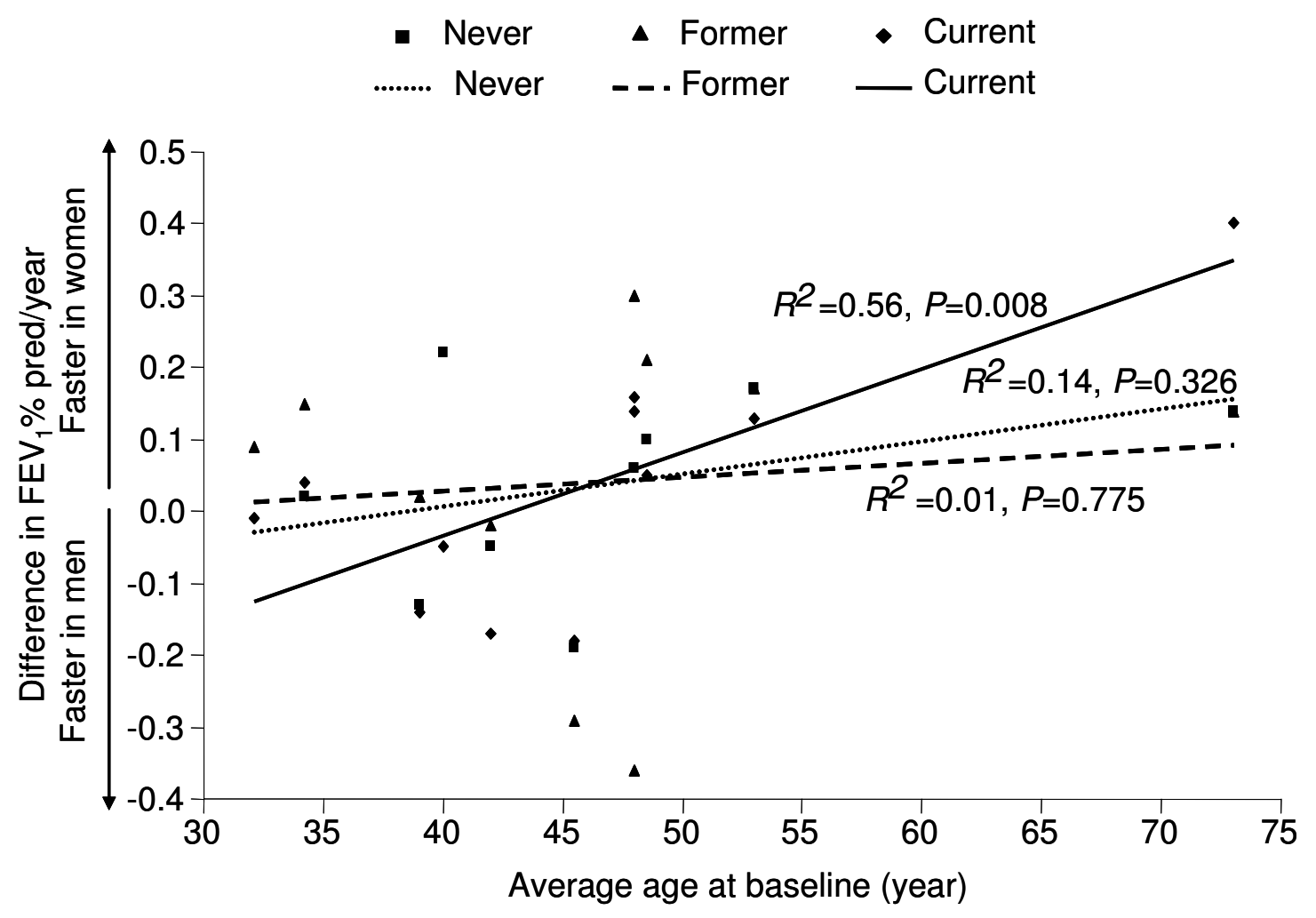

Figure 2

Unweighted analysis of the relationship between age and gender-related differences in the annual decline in FEV $1 \%$ pred according to smoking status Abbreviation: $\mathrm{FEV}_{1}$ : forced expiratory volume in one second.

ments of daily tobacco consumption and years of smoking, female smokers had a higher risk of hospitalization for COPD compared with male smokers (relative risk, RR, $1.5,95 \%$ confidence interval, $\mathrm{CI}, 1.2-2.1$ in the CCHS and RR, 3.6, 95\% CI, 1.4-9.0 in the GPS) [24]. Furthermore, women with impaired lung function $\left(\mathrm{FEV}_{1}<40 \%\right.$ pred) had a higher risk of death from all causes (RR, 5.0 for women, 2.7 for men) and of deaths from obstructive lung diseases (RR, 57 for women, 34 for men,) compared with men [25]. Xu and colleagues studied 1618 male and 1669 female adults aged 40-69 yrs in the Beijing Respiratory Health Study [28]. Although female never smokers had better lung function than did male never smokers, female current smokers had significantly lower lung function compared with male smokers [28]. In a genetics study of early onset COPD, Silverman and colleagues found that female first-degree current or ex-smoking relatives of the probands were almost two times more likely to demonstrate mild airflow limitation $\left(\mathrm{FEV}_{1}<80 \%\right.$ predicted) and over three times more likely to have severe airflow limitation $\left(\mathrm{FEV}_{1}<40 \%\right.$ predicted) than did male relatives [29].

Although the present study did not evaluate effects of smoking cessation on lung function in men and women, data from the Lung Health Study indicates that female quitters may experience larger gains in lung function than do male sustained quitters. In that study, female sustained quitters experienced a 2.5 fold larger improvement in $\mathrm{FEV}_{1} \%$ pred than did male sustained quitters after one year of smoking cessation [30]. These data, in conjunction with results of the present systematic review, suggest that female smokers have increased susceptibility for COPD, 


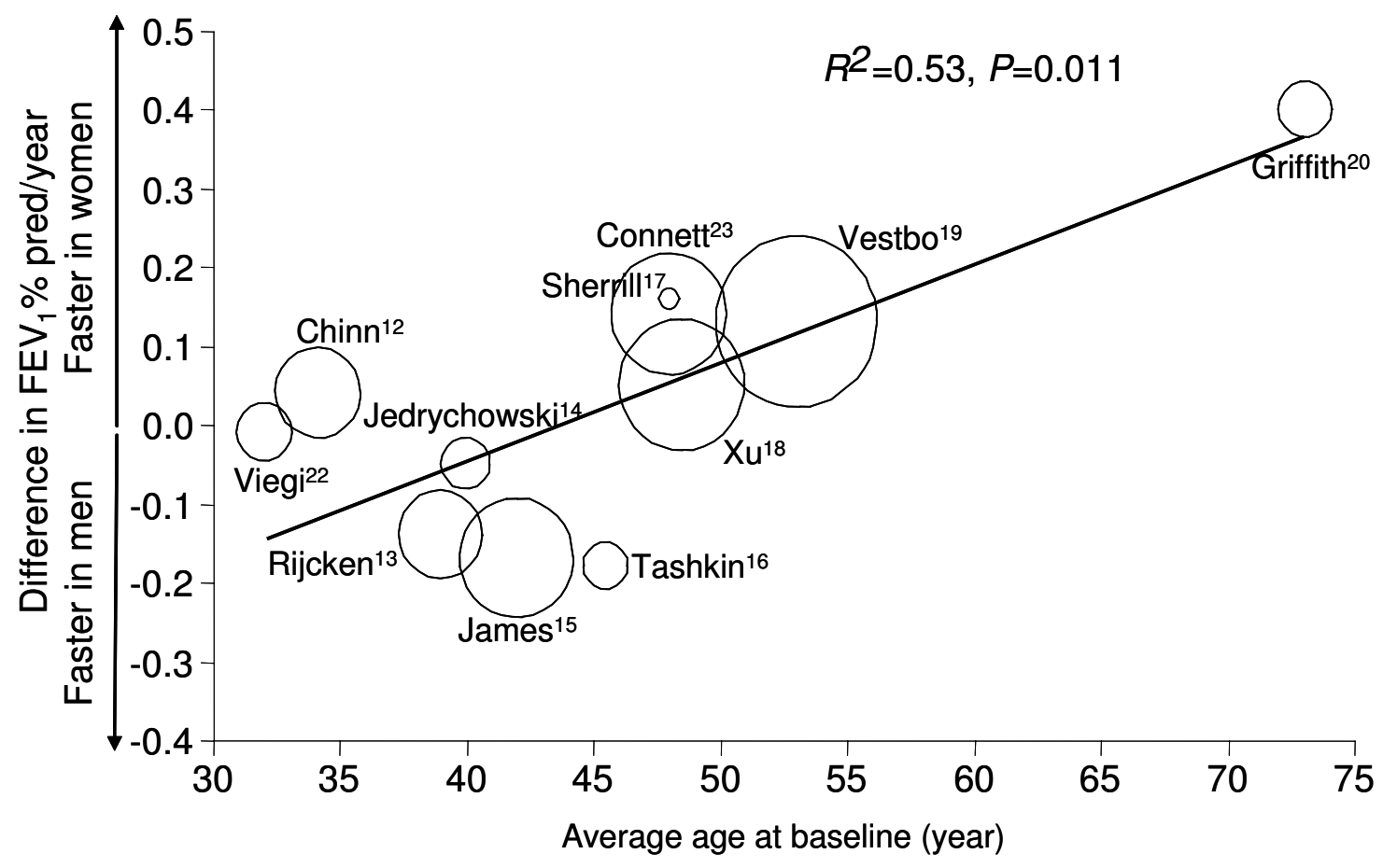

Figure 3

Weighted analysis of the relationship between age and gender-related differences in the annual decline in FEV ${ }_{1} \%$ pred for current smokers The regression line is weighted by the numbers of current smokers. The diameter of

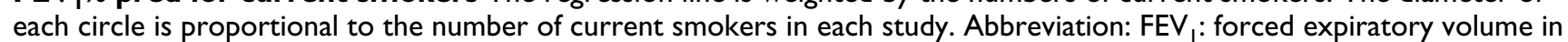
one second.

especially after age 45 to 50 years. With smoking cessation, however, female quitters may experience a larger recovery of their lung function than do male quitters.

Although our study was not designed to evaluate the effects of smoking in adolescent youths, previous studies indicate that smoking may also have a greater (negative) impact on lung growth in female than male youngsters. Gold et al [31] found that among adolescents, smoking five or more cigarettes a day, as compared with never smokers, was associated with a $1.09 \%$ per year reduction in the growth rate of $\mathrm{FEV}_{1}$ in girls, while for boys, smoking reduced $\mathrm{FEV}_{1}$ growth by only $0.20 \% / \mathrm{yr}$. Patel et al [27] found that exposure to cigarette smoke during childhood was an independent risk factor for the development of obstructive airways disease in women but not in men.
Thus, the relationship between gender, age and $\mathrm{FEV}_{1}$ changes may be U-shaped.

The mechanisms responsible for the increased susceptibility of women to cigarette smoke are largely unknown. There is now a general consensus that inflammation is at the heart of the pathobiology of COPD and that the inflammatory process involves both the lung (airways and parenchyma) and the systemic circulation [32-34]. The intensity of the inflammatory process in the airways and in the systemic circulation is associated with severity of $\mathrm{FEV}_{1}$ impairment [33,34]. Whether women are more likely to demonstrate airway inflammation compared with men is unknown. Interestingly, women in the general population are known to have higher circulating $\mathrm{C}$ reactive protein levels, a marker of systemic inflamma- 
tion, but only after $\sim 50$ years of age [35]. Since active smoking amplifies systemic inflammation, independent of other factors [36], smoking-inflammation pathway may be an important contributor to the increased risk observed in women in the peri and post-menopausal periods. Further research is needed to confirm this hypothesis.

Another potential mechanism may relate to bronchial hyperresponsiveness. In the Lung Health Study, there was a higher prevalence of bronchial hyperresponsiveness among women than among men $(85 \%$ in women versus $59 \%$ of the men) [37]. In another population-based study, Leynaert and coworkers demonstrated increased prevalence of bronchial hyperresponsiveness in women, even after adjustments for respiratory symptoms, atopy, or lung function parameters [38]. Paoletti et al [39] also found increased risk of bronchial hyperresponsiveness among women compared with men independent of baseline lung function. In women, they observed that current smokers had significantly more reactive airways than did non- or ex-smokers. However, in men, smoking status made no material impact on bronchial responsiveness [39]. These data may be clinically relevant since bronchial hyperresponsiveness has been associated with increased risk of both COPD progression [40] and COPD mortality [41].

Additionally, cigarette smoke may modify hormonal status in women, which may affect lung function. Women who are active smokers become relatively estrogen deficient compared with non-smokers because cigarette smoke induces cytochrome P450 isoenzymes CYP1A1 and CYP1A2, which alter estrogen metabolism leading to increased production of inactive catechols [42]. Hormone replacement therapy in the post-menopausal period is associated with improved lung function, reducing the risk of airflow obstruction by 25\% [43]. Hormone replacement therapy also reduces bronchial hyperresponsiveness in post-menopausal women [44].

An alternative hypothesis for higher susceptibility of females to smoking may be differences in lung development between females and males. Interestingly, relative to male rates, female rates of obstructive airway diseases increase sharply during adolescence [45]. Before pubescence, girls have smaller lung volumes than do boys but generate higher flows [46]. During teenage years, airways and lung volumes demonstrate isotropic growth in boys. In girls, however, airway growth becomes disproportionately smaller relative to lung volume growth, indicating dysanapsis [47]. Thus, for any given lung volume and size, women have smaller airways compared with men, which may make the airways more susceptible to the adverse effects of cigarette smoke.
There were several limitations to the study. Firstly, we used only a crude marker of smoking (i.e. self-report of smoking). Since male smokers generally smoke more cigarettes than do female smokers and have a longer smoking history, we may have underestimated the true effects of cigarette smoking in the female population [9]. Secondly, as with most systematic reviews, publication bias is a source of concern. Figure 3 indicates that there were no material differences in results between large and small studies, suggesting that publication bias did not significantly affect the results.

\section{Conclusion}

We found that beyond age 45 to 50 years, female smokers appear to experience an accelerated decline in $\mathrm{FEV}_{1} \%$ pred/yr compared with male smokers. Additional prospective longitudinal studies powered specifically on gender-related changes in lung function in the postmenopausal age group are needed to confirm these observations. In view of the growing incidence of smoking and the COPD in the female population, there is an urgent need to promote smoking abstinence and cessation in the female population.

\section{Abbreviations}

CCHS: Copenhagen City Heart Study

COPD: chronic obstructive pulmonary disease

$\mathrm{FEV}_{1}$ : forced expiratory volume in one second

GPS: Glostrup Population Studies

Pred: predicted

RR: relative risk

Yr: year

\section{Competing interests}

This project is supported by ICEBERGS (Interdisciplinary Capacity Enhancement: Bridging Excellence in Respiratory Disease and Gender Studies), which is funded by the Canadian Institutes of Health Research (IGH / ICRH), the Canadian Lung Association, and the Heart and Stroke Foundation of Canada.

\section{Authors' contributions}

All authors have made substantial intellectual contribution to the interpretation of the results and drafting of the manuscript.

\section{Acknowledgements}

The authors thank Dr. Giovanni Viegi for providing additional data for this study as well as all the other authors of the primary studies who contributed their time and data to this project. 


\section{References}

I. Murray CJ, Lopez AD: Alternative projections of mortality and disability by cause 1990-2020: Global Burden of Disease Study. Lancet 1997, 349:|498-I504.

2. Brown CA, Crombie IK, Tunstall-Pedoe H: Failure of cigarette smoking to explain international differences in mortality from chronic obstructive pulmonary disease. J Epidemiol Community Health 1994, 48: I34-139.

3. Michaud CM, Murray CJ, Bloom BR: Burden of disease - implications for future research. JAMA 200I, 285:535-539.

4. Sullivan SD, Ramsey SD, Lee TA: The economic burden of COPD. Chest 2000, I I 7:5S-9S.

5. Mannino DM, Homa DM, Akinbami LJ, Ford ES, Redd SC: Chronic obstructive pulmonary disease surveillance - United States, | 97 |-2000. MMWR Surveill Summ 2002, 5 I: I- I6.

6. Zorrilla-Torras B, Garcia-Marin N, Galan-Labaca I, GandarillasGrande A: Smoking attributable mortality in the community of Madrid: I 992-1998. Eur J Public Health 2005, I 5:43-50.

7. U.S. Department of Health and Human Services: Reducing tobacco use: a report of the Surgeon General. Atlanta, Georgia: U.S. Department of Health and Human Services, CDC; 2000.

8. Centers for Disease control: Cigarette Smoking Among Adults - United States. 2003 [http://www.cdc.gov/mmwr/preview/ mmwrhtml/mm5420a3.htm\#tab]

9. Gillum RF: Frequency of attendance at religious services and cigarette smoking in American women and men: the Thirc National Health and Nutrition Examination Survey. Prev Med 2005, 4I:607-6I3.

10. Fletcher $C$, Peto R: The natural history of chronic airflow obstruction. $\mathrm{Br}$ Med J 1977, I: I645- I648.

II. Pauwels RA, Rabe KF: Burden and clinical features of chronic obstructive pulmonary disease (COPD). Lancet 2004, 364:613-620.

12. Chinn S, Jarvis D, Melotti R, Luczynska C, Ackermann-Liebrich U, Anto JM, Cerveri I, de Marco R, Gislason T, Heinrich J, Janson C, Kunzli N, Leynaert B, Neukirch F, Schouten J, Sunyer J, Svanes C, Vermeire $P$, Wjst $M$, Burney $P$ : Smoking cessation, lung function, and weight gain: a follow-up study. Lancet 2005, 365:1629-1635.

13. Rijcken B, Schouten JP, Xu X, Rosner B, Weiss ST: Airway hyperresponsiveness to histamine associated with accelerated decline in FEVI. Am J Respir Crit Care Med I995, I 5 I: | 377- I 382.

14. Jedrychowski W, Krzyzanowski M, Wysocki M: Changes in lung function determined longitudinally compared with decline assessed cross-sectionally. The Cracow Study. Eur J Epidemiol 1986, 2:134-138.

15. James AL, Palmer LJ, Kicic E, Maxwell PS, Lagan SE, Ryan GF, Musk AW: Decline in lung function in the Busselton Health Study: the effects of asthma and cigarette smoking. Am J Respir Crit Care Med 2005, I71:109-1 14.

16. Tashkin DP, Clark VA, Coulson AH, Simmons M, Bourque LB, Reems C, Detels R, Sayre JW, Rokaw SN: The UCLA population studies of chronic obstructive respiratory disease. VIII. Effects of smoking cessation on lung function: a prospective study of a free-living population. Am Rev Respir Dis 1984, I 30:707-7I 5.

17. Sherrill DL, Enright P, Cline M, Burrows B, Lebowitz MD: Rates of decline in lung function among subjects who restart cigarette smoking. Chest 1996, 109:1001-1005.

18. Xu X, Dockery DW, Ware JH, Speizer FE, Ferris BG Jr: Effects of cigarette smoking on rate of loss of pulmonary function in adults: a longitudinal assessment. Am Rev Respir Dis 1992, | 46: | 345-1348.

19. Vestbo J, Prescott E, Lange P: Association of chronic mucus hypersecretion with FEVI decline and chronic obstructive pulmonary disease morbidity. Copenhagen City Heart Study Group. Am J Respir Crit Care Med 1996, I53:1530-I535.

20. Griffith KA, Sherrill DL, Siegel EM, Manolio TA, Bonekat HW, Enright PL: Predictors of loss of lung function in the elderly: the Cardiovascular Health Study. Am J Respir Crit Care Med 200I, 1 63:61-68.

21. Hankinson JL, Odencrantz JR, Fedan KB: Spirometric reference values from a sample of the general U.S. population. Am J Respir Crit Care Med 1999, I 59:179-I87.

22. Viegi G, Sherrill DL, Carrozzi L, Di Pede F, Baldacci S, Pistelli F, Enright P: An 8-year follow-up of carbon monoxide diffusing capacity in a general population sample of northern italy. Chest 200I, I 20:74-80.
23. Connett JE, Murray RP, Buist AS, Wise RA, Bailey WC, Lindgren PG, Owens GR, Lung Health Study Research Group: Changes in smoking status affect women more than men: results of the Lung Health Study. Am J Epidemiol 2003, I 57:973-979.

24. Prescott E, Bjerg AM, Andersen PK, Lange P, Vestbo J: Gender difference in smoking effects on lung function and risk of hospitalization for COPD: results from a Danish longitudinal population study. Eur Respir J 1997, 10:822-827.

25. Lange P, Nyboe J, Appleyard M, Jensen G, Schnohr P: Relation of ventilatory impairment and of chronic mucus hypersecretion to mortality from obstructive lung disease and from all causes. Thorax 1990, 45:579-585.

26. Downs SH, Brandli O, Zellweger JP, Schindler C, Kunzli N, Gerbase MW, Burdet L, Bettschart R, Zemp E, Frey M, Keller R, Tschopp JM, Leuenberger P, Ackermann-Liebrich U, SAPALDIA team: Accelerated decline in lung function in smoking women with airway obstruction: SAPALDIA 2 cohort study. Respir Res 2005, 6:45.

27. Patel BD, Luben RN, Welch AA, Bingham SA, Khaw KT, Day NE, Lomas DA, Wareham NJ: Childhood smoking is an independent risk factor for obstructive airways disease in women. Thorax 2004, 59:682-686.

28. Xu X, Li B, Wang L: Gender difference in smoking effects on adult pulmonary function. Eur Respir 」 1994, 7:477-483.

29. Silverman EK, Chapman HA, Drazen JM, Weiss ST, Rosner B, Campbell EJ, O'DONNELL WJ, Reilly J], Ginns L, Mentzer S, Wain J, Speizer FE: Genetic epidemiology of severe, early-onset chronic obstructive pulmonary disease. Risk to relatives for airflow obstruction and chronic bronchitis. Am J Respir Crit Care Med 1998, 157:1770-1778.

30. Scanlon PD, Connett JE, Waller LA, Altose MD, Bailey WC, Buist AS: Smoking cessation and lung function in mild-to-moderate chronic obstructive pulmonary disease. Am J Respir Crit Care Med 2000, I 6 I:381-390.

31. Gold DR, Wang X, Wypij D, Speizer FE, Ware JH, Dockery DW: Effects of cigarette smoking on lung function in adolescent boys and girls. N Engl J Med 1996, 335:931-937.

32. Barnes PJ, Shapiro SD, Pauwels RA: Chronic obstructive pulmonary disease: molecular and cellular mechanisms. Eur Respir J 2003, 22:672-688.

33. Hogg JC, Chu F, Utokaparch S, Woods R, Elliott WM, Buzatu L, Cherniack RM, Rogers RM, Sciurba FC, Coxson HO, Pare PD: The nature of small-airway obstruction in chronic obstructive pulmonary disease. N Engl J Med 2004, 350:2645-2653.

34. Sin DD, Man SF: Why are patients with chronic obstructive pulmonary disease at increased risk of cardiovascular diseases? The potential role of systemic inflammation in chronic obstructive pulmonary disease. Circulation 2003, 107:1514-1519.

35. Hutchinson WL, Koenig W, Frohlich M, Sund M, Lowe GD, Pepys MB: Immunoradiometric assay of circulating $C$-reactive protein: age-related values in the adult general population. Clin Chem 2000, 46:934-938.

36. Gan WQ, Man SF, Sin DD: The interactions between cigarette smoking and reduced lung function on systemic inflammation. Chest 2005, I 27:558-564.

37. Tashkin DP, Altose MD, Bleecker ER, Connett JE, Kanner RE, Lee WW, Wise R: The lung health study: airway responsiveness to inhaled methacholine in smokers with mild to moderate airflow limitation. The Lung Health Study Research Group. Am Rev Respir Dis 1992, 145:301-310.

38. Leynaert B, Bousquet J, Henry C, Liard R, Neukirch F: Is bronchial hyperresponsiveness more frequent in women than in men? A population-based study. Am J Respir Crit Care Med 1997, I56:1413-1420.

39. Paoletti P, Carrozzi L, Viegi G, Modena P, Ballerin L, Di Pede F, Grado L, Baldacci S, Pedreschi M, Vellutini M: Distribution of bronchial responsiveness in a general population: effect of sex, age, smoking, and level of pulmonary function. Am J Respir Crit Care Med 1995, I 5 I:1770-1777.

40. Tashkin DP, Altose MD, Connett JE, Kanner RE, Lee WW, Wise RA: Methacholine reactivity predicts changes in lung function over time in smokers with early chronic obstructive pulmonary disease. The Lung Health Study Research Group. Am J Respir Crit Care Med 1996, I 53:I802-I8II.

4I. Hospers J], Postma DS, Rijcken B, Weiss ST, Schouten JP: Histamine airway hyper-responsiveness and mortality from chronic 
obstructive pulmonary disease: a cohort study. Lancet 2000, 356:1313-1317.

42. Baron JA, La Vecchia C, Levi F: The antiestrogenic effect of cigarette smoking in women. Am J Obstet Gynecol 1990, 162:502-5।4.

43. Carlson CL, Cushman M, Enright PL, Cauley JA, Newman AB, Cardiovascular Health Study Research Group: Hormone replacement therapy is associated with higher FEVI in elderly women. Am J Respir Crit Care Med 200I, 163:423-428.

44. Mueller JE, Frye C, Brasche S, Heinrich J: Association of hormone replacement therapy with bronchial hyper-responsiveness. Respir Med 2003, 97:990-992.

45. Skobeloff EM, Spivey WH, St Clair SS, Schoffstall JM: The influence of age and sex on asthma admissions. JAMA 1992, 268:3437-3440.

46. Hibbert ME, Couriel JM, Landau LI: Changes in lung, airway, and chest wall function in boys and girls between 8 and 12 yr. J Appl Physiol 1984, 57:304-308.

47. Merkus PJ, Borsboom GJ, Van Pelt W, Schrader PC, Van Houwelingen HC, Kerrebijn KF, Quanjer PH: Growth of airways and air spaces in teenagers is related to sex but not to symptoms. J Appl Physiol 1993, 75:2045-2053.

Publish with Bio Med Central and every scientist can read your work free of charge

"BioMed Central will be the most significant development for disseminating the results of biomedical research in our lifetime. "

Sir Paul Nurse, Cancer Research UK

Your research papers will be:

- available free of charge to the entire biomedical community

- peer reviewed and published immediately upon acceptance

- cited in PubMed and archived on PubMed Central

- yours - you keep the copyright

Submit your manuscript here:

http://www.biomedcentral.com/info/publishing_adv.asp 